\title{
Postharvest Decay Management for Stone Fruit Crops in California Using the "Reduced-Risk" Fungicides Fludioxonil and Fenhexamid
}

\author{
H. Förster, Department of Plant Pathology, University of California, Davis 95616; G. F. Driever, Department of \\ Plant Pathology, University of California, Riverside 92521; D. C. Thompson, IR-4 Project, Rutgers University, North \\ Brunswick, NJ 08902; and J. E. Adaskaveg, Department of Plant Pathology, University of California, Riverside
}

\begin{abstract}
Förster, H., Driever, G. F., Thompson, D. C., and Adaskaveg, J. E. 2007. Postharvest decay management for stone fruit crops in California using the "reduced-risk" fungicides fludioxonil and fenhexamid. Plant Dis. 91:209-215.

In laboratory studies and experimental packingline trials that closely simulated fungicide treatments under commercial conditions, the "reduced-risk" fungicides fenhexamid and fludioxonil were highly effective in managing postharvest brown rot and gray mold decays of peach, nectarine, and plum caused by Monilinia fructicola and Botrytis cinerea, respectively. Tebuconazole was more effective against brown rot than against gray mold. Additionally, fludioxonil and tebuconazole significantly reduced the incidence of Rhizopus rot caused by Rhizopus stolonifer. In laboratory studies, the QoI fungicide azoxystrobin was not consistent in its decay control activity. The high efficacy of fenhexamid and fludioxonil against brown rot and gray mold was substantiated by low effective concentrations necessary $(\leq 0.063 \mathrm{mg} / \mathrm{liter})$ for $50 \%$ inhibition of mycelial growth in vitro. In general, fungicides applied 14 to $16 \mathrm{~h}$ after wound inoculation were significantly more effective than those applied before inoculation. These results indicate that the fungicides act mainly as protectants that do not penetrate deeply enough into the fruit to prevent decay from wounds that extend below the fruit epidermis. Laboratory treatments of plum fruit generally were less effective than those of peach or nectarine fruit. Comparative studies using either low-volume spray or high-volume, in-line drench applications over a roller bed demonstrated that drench applications were significantly more effective in reducing postharvest decays of inoculated plum fruit. Decay incidence using fenhexamid or fludioxonil was $\leq 1.1 \%$, whereas incidence after the spray applications was between 25.2 and $40.4 \%$ for brown rot, between 12.0 and $24.3 \%$ for gray mold, or $62.6 \%$ for Rhizopus rot (fludioxonil only). This research identified effective replacements for iprodione, a fungicide voluntarily canceled by the manufacturer in 1996.
\end{abstract}

Additional keywords: baseline sensitivities, fungicide resistance

The major postharvest decays of stone fruit crops in California and other production areas in the United States and elsewhere are brown rot, caused by Monilinia fructicola (G. Wint.) Honey or, less commonly in some areas, M. laxa (Aderhold \& Ruhland) Honey; gray mold, caused by Botrytis cinerea Pers.:Fr.; and Rhizopus rot, caused by Rhizopus stolonifer (Ehrenb.:Fr.) Vuill (21). On nectarine, peach, and plum, brown rot is the more important decay (18) and, in spite of California's relatively dry climate, losses from postharvest decays can be substantial in some years. Consequently, marketing of decay-free fruit, especially to longdistance markets, can be problematic without postharvest fungicide treatments. Decay fungi are primarily wound pathogens.

Corresponding author: J. E. Adaskaveg

E-mail: jim.adaskaveg@ucr.edu

Accepted for publication 14 September 2006.

DOI: 10.1094/PDIS-91-2-0209

(C) 2007 The American Phytopathological Society
Thus, postharvest decays mainly develop from injuries that occur before and, most importantly, during or after harvest. Once fungal spores are deposited into these wounds, rapid fruit decay can occur. Germinating conidia of Monilinia spp., however, also can penetrate the intact fruit cuticle and then become established inside the host. In addition, Monilinia spp. and $B$. cinerea also are known to cause quiescent infections on immature fruit that are more resistant to fungal invasion (3). These infections develop into active decay when fruit mature and become susceptible. In most years, however, quiescent infections are considered only a minor cause of postharvest fruit decay (8). In contrast, $R$. stolonifer mainly infects ripe fruit after harvest, unless fruit in the field have major injuries or split pits. With a variety of postharvest decay pathogens causing crop losses and a range of different infection methods, postharvest decay control is challenging.

Although the incidence of postharvest decays can be reduced by preharvest strategies and by postharvest temperature control and sanitation practices, posthar- vest fungicides are an important and effective component in the integrated management of decays (2). Ideally, these fungicides protect the fruit from decay originating from infections that occurred before treatment, including quiescent infections, as well from infections that are initiated after treatment during postharvest handling, shipment, and marketing. Iprodione was registered for postharvest brown rot, gray mold, and Rhizopus rot control of stone fruit crops in the past $(2,4,17)$. This fungicide, however, was canceled voluntarily for postharvest use by the registrant in 1996 as a result of the United States Environmental Protection Agency (EPA) reregistration policy of older pesticides mandated by federal law in 1988 . Other postharvest fungicides that were not reregistered included benomyl, thiophanate-methyl, and triforine (2). The registrants of the latter products found it too costly to reregister for the low-profit postharvest market. Dichloran, which is mostly active against Rhizopus rot and is less effective against brown rot and gray mold, was the only older fungicide that was reregistered for postharvest use on stone fruit in the United States (2). The high cost of dichloran after reregistration and the lack of a highly effective brown rot fungicide stimulated our research to find a replacement for iprodione.

Thus, in this study, we describe the evaluation of the recently introduced preharvest fungicides fenhexamid, tebuconazole, and azoxystrobin, as well as fludioxonil. These materials belong to the hydroxyanilide, sterol biosynthesis inhibiting-triazole, QoI fungicide classes, and phenylpyrrole, respectively, and were selected because they already were registered for preharvest use on stone fruit or their registrants supported postharvest use. Objectives of our research included characterization of the activity spectra of these materials and the evaluation of their efficacy as pre- and post-infection treatments for postharvest management of the three major postharvest decays (i.e., brown rot, gray mold, and Rhizopus rot) of peach, nectarine, and plum. In addition, we characterized the in vitro toxicity of fludioxonil and fenhexamid against $M$. fructicola and B. cinerea.

\section{MATERIALS AND METHODS}

Fungal isolates and cultural practices. Isolates of M. fructicola, B. cinerea, and $R$. 
stolonifer were obtained from decayed stone fruit (peach, plum, nectarine, pluot, and sweet cherry) throughout California between 1992 and 2003. For production of spore inoculum, M. fructicola was grown in the dark at $25^{\circ} \mathrm{C}$ on clarified V8 juice agar (19), B. cinerea was grown on King's medium $\mathrm{B}(6)$ at $25^{\circ} \mathrm{C}$ under laboratory lighting conditions, and $R$. stolonifer was grown on potato dextrose agar (Difco Laboratories, Detroit) at $25^{\circ} \mathrm{C}$ in the dark. For fruit inoculation studies, the same isolate of each fungus was used in all studies (e.g., M. fructicola isolate 90, B. cinerea isolate 1356, and $R$. stolonifer isolate $1535)$. Stock cultures were stored in liquid nitrogen.

Fungicides used. Fungicides evaluated included azoxystrobin (Abound 2.08F; Syngenta Crop Protection, Greensboro, NC), fenhexamid (Elevate 50WG; Arysta Life Sciences, San Francisco), fludioxonil (Scholar 50WP; Syngenta Crop Protection), iprodione (Rovral 50WP; Bayer Crop-Science, Kansas City, MO), and tebuconazole (Elite 45WP; Bayer CropScience). Rates evaluated were based on manufacturers' recommendations for nonpostharvest-use applications and our experience with preharvest use with each fungicide. For postharvest laboratory and packingline drench applications, rates were $225 \mathrm{mg} /$ liter for azoxystrobin, $900 \mathrm{mg} / \mathrm{liter}$ for fenhexamid, $300 \mathrm{mg} / \mathrm{liter}$ for fludioxonil, 1,200 mg/liter for iprodione, and $270 \mathrm{mg} /$ liter for tebuconazole using treatment volumes equivalent to 42 liters per $10,000 \mathrm{~kg}$ of fruit. Fungicide rates for the low-volume packingline spray applications were $5.4 \mathrm{~g} / \mathrm{liter}$ for fenhexamid, $1.8 \mathrm{~g} / \mathrm{liter}$ for fludioxonil, $7.2 \mathrm{~g} /$ liter for iprodione, and $1.62 \mathrm{~g} /$ liter for tebuconazole using treatment volumes of 6.7 liters per $10,000 \mathrm{~kg}$ of fruit. Based on these rates and treatment volumes, the same empirical amounts of each fungicide were applied to the fruit using the different application methods (e.g., $9.34 \mathrm{~g}$ of azoxystrobin, $37.5 \mathrm{~g}$ of fenhexamid, $12.5 \mathrm{~g}$ of fludioxonil, $50 \mathrm{~g}$ of iprodione, or $11.25 \mathrm{~g}$ of tebuconazole per $10,000 \mathrm{~kg}$ of fruit). In a laboratory rate study with fludioxonil, selected rates between 50 to $300 \mathrm{mg} / \mathrm{liter}$ for nectarine and 100 to $600 \mathrm{mg} / \mathrm{liter}$ for plum also were evaluated.

Determination of fenhexamid and fludioxonil effective concentrations for in vitro inhibition of mycelial growth. For fenhexamid and fludioxonil, effective concentration values for a $50 \%$ inhibition of mycelial growth $\left(\mathrm{EC}_{50}\right)$ of isolates of $B$. cinerea and $M$. fructicola collected from stone fruit hosts were determined using the spiral gradient dilution method (11). For $B$. cinerea, 14 isolates were used for both fungicides; whereas, for M. fructicola, 62 isolates were used for fludioxonil and 31 isolates for fenhexamid. Fungicide stock concentrations of 20 to $50 \mathrm{mg} / \mathrm{liter}$ were spirally applied to $15-\mathrm{cm}$ petri dishes with potato dextrose agar using a spiral plater
(Autoplate 4000; Spiral Biotech, Norwood, MA). Experimental procedures were as described previously (11), except that, instead of mycelium-covered cellophane strips, a conidial suspension $\left(10 \mu\right.$ of $10^{6}$ conidia/ml) was streaked radially across the fungicide concentration gradient on the spiral gradient dilution plate. A duplicate sample of each isolate was placed at opposite locations of two replicated plates and each isolate was evaluated in two experiments. Plates were incubated for 3 days at $25^{\circ} \mathrm{C}$. Radial distances for $\mathrm{EC}_{50}$ for mycelial growth then were determined and entered into the Spiral Gradient Endpoint computer program (Spiral Biotech). Data were averaged for the duplicate plates from each experiment and standard errors were calculated for the mean values.

Postharvest laboratory treatments for brown rot, gray mold, and Rhizopus rot control. Stone fruit used included peach (cv. Elegant Lady), nectarine (cv. Red Diamond), and plum (cv. Casselman). Fruit were grown in an experimental orchard at the University of California, Kearney Agricultural Center in Parlier, CA, using methods similar to commercial practices, but received no preharvest fungicide treatments. All postharvest treatments were used in combination with a postharvest emulsified mineral oil-based fruit coating (Decco Peach, Plum, and Nectarine Lustr 251; Cerexagri-Decco, Monrovia, CA) diluted in water to $25 \%$ (vol/vol; $6.25 \%$ soluble solids) for peach and nectarine and to 50 to $75 \%$ (vol/vol; 12.5 to $18.75 \%$ soluble solids) for plum and were applied to the inoculated side of the fruit using an atomizer (DeVilbiss 15-RD; Sunrise Medical, Inc., Somerset, PA). Control fruit were treated with only the stone fruit coating. Treatment volumes were equivalent to approximately 42 liters per $10,000 \mathrm{~kg}$ of fruit. Two inoculation-treatment schedules were used. In one schedule, fruit first were wounded using a metal tool that provided a $2-\mathrm{mm}$ deep and 2-mm wide injury, then inoculated with a 20- $\mu \mathrm{l}$ droplet of an inoculum suspension $(30,000$ conidia or spores $/ \mathrm{ml})$, incubated for 12 to $16 \mathrm{~h}$ at $20^{\circ} \mathrm{C}$, and then treated. In the other schedule, fruit first were treated, incubated for 5 to $12 \mathrm{~h}$ at $20^{\circ} \mathrm{C}$, and then wound inoculated. After incubation at $20^{\circ} \mathrm{C}$ and $>85 \%$ relative humidity for 4 to 6 days in commercial fruit trays and boxes, fruit were evaluated for incidence of decay (percentage of fruit with any size decay lesions of the total number of fruit). Three or four replications of 8 to 12 fruit were used in each experiment and experiments were done twice.

Postharvest experimental packingline treatments for brown rot, gray mold, and Rhizopus rot control. The experimental packingline at the University of California Kearney Agricultural Center in Parlier is similar to a commercial packingline (overall dimensions, 90 by $1,140 \mathrm{~cm}$ ) and is equipped to treat fruit using several high- and low-volume application methods over moving roller or brush beds with treatment areas $90 \mathrm{~cm}$ wide and 90 to $120 \mathrm{~cm}$ long. Before fungicide application, fruit were washed in the wash section of the brush bed for $15 \mathrm{~s}$ with a $100-\mathrm{mg} / \mathrm{liter}$ sodium hypochlorite solution, rinsed with water for 10 $\mathrm{s}$ (both at a rate of $120 \mathrm{ml} / \mathrm{s}$ ), and then dried by passing over a sponge-roller bed in the water-elimination section of the packingline. For low-volume (6.7 liters per $10,000 \mathrm{~kg}$ of fruit) spray applications, a controlled droplet applicator (CDA; Cerexagri-Decco) that was positioned in the center of the treatment area and about 40 $\mathrm{cm}$ above the brush bed or about $20 \mathrm{~cm}$ above the roller bed was used. High-volume in-line drenches were applied to plum fruit by pumping a fungicide solution from a 70liter reservoir into a perforated steel distribution pan (91-by-91-cm area with 127 5$\mathrm{mm}$ holes evenly distributed) over the moving roller bed. Treatment volumes per fruit weight for the spray applications were adjusted to the desired specifications by adjusting fungicide output volumes and speed of fruit movement through the treatment area. Treatment times were generally between 12 and $15 \mathrm{~s}$. Between treatments, fungicide reservoirs and tubing as well as treatment beds were treated with a commercial alkaline detergent (PacFoam Plus; Pace International, Seattle) and then thoroughly rinsed with water. For the spray applications, fungicides were applied in a fruit coating. An emulsified mineral-oil-based coating (Decco Peach, Plum, and Nectarine Lustr 251) was used for nectarine and peach, and a carnauba wax-based coating (Primafresh Ultra; Pace International) was used for plum. Fruit coatings were used undiluted or diluted to $50 \%$ (vol/vol). In the in-line drenches, fungicides were applied as aqueous solutions, and drenches were followed by a low-volume application of a fruit coating as described above. Control fruit were treated only with the fruit coating. The same fruit inoculation-treatment schedules were used as for the laboratory experiments described above. After treatment, fruit were packed into commercial fruit trays and boxes and incubated as for the laboratory experiments. For each treatment, four replications of 12 to 24 nectarine or peach fruit or 40 plum fruit were used and experiments were done twice.

Statistical analysis of data. For both laboratory and experimental packingline studies, data for repeated experiments were combined and evaluated using Bartlett's test of homogeneity of variances. Arcsine transformations were used for decay incidence data. Because variances were homogeneous, combined data sets then were analyzed using a balanced factorial design. The effects of fungicide treatments were evaluated for different inoculationtreatment schedules, fruit hosts, and pathogens. Transformed values were analyzed using general linear model and mean sepa- 
ration procedures of SAS (version 9.1; SAS Institute, Cary, NC). Linear regression analysis was used to evaluate rates of fludioxonil on the average incidence of decay for brown rot, gray mold, and Rhizopus rot of nectarine and plum fruit using SAS. Specific rates evaluated were over a narrow range within the linear portion of a sigmoidal response curve to the fungicide. For oxonil and fenhexamid for M. fructicola and $B$. cinerea, average $\mathrm{EC}_{50}$ values and their standard error are shown.

\section{RESULTS}

Determination of fenhexamid and fludioxonil $\mathrm{EC}_{50}$ values for in vitro inhibition of mycelial growth. $\mathrm{EC}_{50}$ values for fenhexamid and fludioxonil were determined for isolates of $B$. cinerea and $M$. fructicola. For fludioxonil, values ranged from 0.005 to $0.021 \mathrm{mg} / \mathrm{liter}$ and from 0.004 to $0.010 \mathrm{mg} / \mathrm{liter}$ for $M$. fructicola and $B$. cinerea (Table 1), respectively; whereas, for fenhexamid, $\mathrm{EC}_{50}$ values ranged from 0.009 to $0.021 \mathrm{mg} /$ liter and from 0.007 to $0.063 \mathrm{mg} / \mathrm{liter}$ for the two decay pathogens, respectively (Table 1). Thus, a wider range of effective concentrations was found for $B$. cinerea for fenhexamid, but values for the most sensitive isolates of each pathogen for each fungicide were quite similar.

Postharvest laboratory treatments for brown rot, gray mold, and Rhizopus rot reporting baseline sensitivities of fludi-

control. The three general linear models used to evaluate fungicide treatments as affected by inoculation-treatment schedule, fruit crop (peach, nectarine, or plum), or decay pathogen all were highly significant $(P<0.0001)$. In addition, fungicide treatment, inoculation-treatment schedule, and their interaction; fungicide treatment, fruit crop, and their interaction; and fungicide treatment, decay pathogen, and their interaction were shown to be highly significant $(P<0.001)$. Thus, because significant interactions occurred between each of these three variables and the fungicide treatment, data in Table 2 are presented separately. In laboratory experiments using nectarine, peach, and plum fruit, brown rot and gray mold decays were significantly reduced when fruit were treated with any one of the fungicides evaluated 12 to $16 \mathrm{~h}$ after wound inoculation with the respective pathogens (Table 2). On peach and nectarine, applications with fludioxonil or fenhexamid consistently resulted in very high levels of decay control, similar to that of the former industry standard, iprodione. Incidences of decay after treatment with fludioxonil or fenhexamid were $<10 \%$, compared with incidences in the untreated control of 65.3 to $87.0 \%$ for brown rot and 93.3 to $95.2 \%$ for gray mold. Tebuconazole was highly effective against brown rot, resulting in no decay, similar to fludioxonil; however, it was less effective for gray mold control with decay incidences of

Table 1. Fenhexamid and fludioxonil effective concentration values for a $50 \%$ inhibition of mycelial growth $\left(\mathrm{EC}_{50}\right)$ of Botrytis cinerea or Monilinia fructicola in vitro ${ }^{z}$

\begin{tabular}{llcccc}
\hline \multicolumn{1}{c}{ Fungus } & Fungicide & No. of isolates & Range of $\mathbf{E C}_{\mathbf{5 0}}$ & ${\text { Mean } \mathbf{E C}_{\mathbf{5 0}}}$ & SE \\
\hline B. cinerea & Fenhexamid & 14 & $0.007-0.063$ & 0.027 & 0.024 \\
M. fructicola & Fenhexamid & 31 & $0.009-0.021$ & 0.015 & 0.003 \\
B. cinerea & Fludioxonil & 14 & $0.004-0.010$ & 0.006 & 0.002 \\
M. fructicola & Fludioxonil & 53 & $0.005-0.021$ & 0.01 & 0.004 \\
\hline
\end{tabular}

${ }^{\mathrm{z}} \mathrm{EC}_{50}$ values were determined on fungicide-amended potato dextrose agar medium; $\mathrm{SE}=$ standard error.
13.3 and $47.6 \%$ for peach and nectarine, respectively. Treatments with azoxystrobin resulted in a brown rot incidence of $0 \%$ for nectarine and 17.4 for peach, whereas gray mold incidence ranged from 34.0 to $40.5 \%$ for the two stone fruit crops. For Rhizopus rot control, fludioxonil was the most effective material evaluated. Decay incidence was reduced to $4.8 \%$ on nectarine and $10 \%$ on peach, compared with 100 and $68.4 \%$, respectively, on untreated control fruit. Tebuconazole and iprodione overall had an intermediate efficacy, whereas fenhexamid and azoxystrobin were either not effective or inconsistent in their efficacy, respectively. On plum, all fungicides also significantly reduced the incidence of decay, but efficacy generally was less than on nectarine and peach, especially for control of gray mold and Rhizopus rot. Incidence of brown rot ranged from $0 \%$ for tebuconazole, $5.4 \%$ for fenhexamid, and $7.1 \%$ for fludioxonil to $8.3 \%$ for azoxystrobin, compared with $30.4 \%$ for iprodione and $96.4 \%$ for the untreated control. Incidence of gray mold was lowest after treatment with fludioxonil (14.3\%) and fenhexamid $(21.4 \%)$ and highest for tebuconazole (62.5\%), compared with $96.4 \%$ incidence in the control. Rhizopus rot was reduced most significantly by azoxystrobin, tebuconazole, and fludioxonil with decay incidences of $16.7,20.8$, and $25 \%$, respectively, compared with $100 \%$ in the control.

When nectarine or peach fruit were inoculated after fungicide application and air drying, treatments with tebuconazole or iprodione again provided excellent brown rot control (incidence of decay between 0 and $1.7 \%$; Table 2). Fludioxonil was highly effective only on the peach fruit that had a decay incidence of $3.4 \%$. Treatments with azoxystrobin or fenhexamid were less effective, but still significantly reduced the incidence of decay compared with the untreated control. For control of gray mold

Table 2. Evaluation of postharvest fungicide treatments for control of brown rot, gray mold, and Rhizopus rot of stone fruits in laboratory experiments ${ }^{\mathrm{w}}$

\begin{tabular}{|c|c|c|c|c|c|c|c|c|c|c|}
\hline \multirow[b]{2}{*}{ Treatment $^{\mathrm{x}}$} & \multirow[b]{2}{*}{ Rate (mg/liter) } & \multicolumn{3}{|c|}{ Incidence brown rot $(\%)$} & \multicolumn{3}{|c|}{ Incidence gray mold (\%) } & \multicolumn{3}{|c|}{ Incidence Rhizopus rot (\%) } \\
\hline & & Peach & Nectarine & Plum & Peach & Nectarine & Plum & Peach & Nectarine & Plum \\
\hline \multicolumn{11}{|c|}{ Inoculated, treated } \\
\hline Control & & $87.0 \mathrm{a}$ & $65.3 \mathrm{a}$ & $96.4 \mathrm{a}$ & $93.3 \mathrm{a}$ & $95.2 \mathrm{a}$ & $96.4 \mathrm{a}$ & $68.4 \mathrm{a}$ & $100.0 \mathrm{a}$ & $100.0 \mathrm{a}$ \\
\hline Iprodione & 1,200 & $1.7 \mathrm{c}$ & $0 \mathrm{~b}$ & $30.4 \mathrm{~b}$ & $13.3 \mathrm{c}$ & $2.4 \mathrm{c}$ & $33.9 \mathrm{bc}$ & $31.0 \mathrm{~b}$ & $35.7 \mathrm{~b}$ & $79.2 \mathrm{ab}$ \\
\hline Azoxystrobin & 225 & $17.4 \mathrm{~b}$ & $0 \mathrm{~b}$ & $8.3 \mathrm{c}$ & $34.0 \mathrm{~b}$ & $40.5 \mathrm{~b}$ & $37.5 \mathrm{bc}$ & $71.4 \mathrm{a}$ & $38.1 \mathrm{~b}$ & $16.7 \mathrm{c}$ \\
\hline Tebuconazole & 270 & $0 \mathrm{c}$ & $0 \mathrm{~b}$ & $0 \mathrm{c}$ & $13.3 \mathrm{c}$ & $47.6 \mathrm{~b}$ & $62.5 \mathrm{~b}$ & $19.0 \mathrm{~b}$ & $31.0 \mathrm{~b}$ & $20.8 \mathrm{c}$ \\
\hline Fenhexamid & 900 & $8.7 \mathrm{bc}$ & $0 \mathrm{~b}$ & $5.4 \mathrm{c}$ & $8.3 \mathrm{c}$ & $4.8 \mathrm{c}$ & $21.4 \mathrm{c}$ & $62.0 \mathrm{a}$ & $97.6 \mathrm{a}$ & $66.7 \mathrm{~b}$ \\
\hline Fludioxonil & 300 & $0 \mathrm{c}$ & $0 \mathrm{~b}$ & $7.1 \mathrm{c}$ & $6.0 \mathrm{c}$ & $2.4 \mathrm{c}$ & $14.3 \mathrm{c}$ & $10.0 \mathrm{~b}$ & $4.8 \mathrm{c}$ & $25.0 \mathrm{c}$ \\
\hline \multicolumn{11}{|c|}{ Treated, inoculated ${ }^{z}$} \\
\hline Control & & $96.6 \mathrm{a}$ & $78.5 \mathrm{a}$ & $100.0 \mathrm{a}$ & $93.3 \mathrm{a}$ & $95.2 \mathrm{a}$ & $100.0 \mathrm{a}$ & $90.0 \mathrm{a}$ & $100.0 \mathrm{a}$ & $100.0 \mathrm{a}$ \\
\hline Iprodione & 1,200 & $1.7 \mathrm{c}$ & $0 \mathrm{~d}$ & $98.0 \mathrm{ab}$ & $0 \mathrm{c}$ & $19.1 \mathrm{c}$ & $87.5 \mathrm{~b}$ & $23.8 \mathrm{c}$ & $69.1 \mathrm{~cd}$ & $100.0 \mathrm{a}$ \\
\hline Azoxystrobin & 225 & $38.3 \mathrm{~b}$ & $21.5 \mathrm{c}$ & $91.1 \mathrm{~b}$ & $70.0 \mathrm{~b}$ & $59.5 \mathrm{ab}$ & $91.7 \mathrm{~b}$ & $86.7 \mathrm{a}$ & $50 \mathrm{~d}$ & $100.0 \mathrm{a}$ \\
\hline Tebuconazole & 270 & $0 \mathrm{c}$ & $0 \mathrm{~d}$ & $0 \mathrm{c}$ & $8.3 \mathrm{c}$ & $61.9 \mathrm{ab}$ & $100.0 \mathrm{a}$ & $53.3 \mathrm{~b}$ & $80.9 \mathrm{bc}$ & $100.0 \mathrm{a}$ \\
\hline Fenhexamid & 900 & $26.0 \mathrm{~b}$ & $40.6 \mathrm{~b}$ & $92.6 \mathrm{ab}$ & $10.0 \mathrm{c}$ & $40.5 \mathrm{bc}$ & $94.6 \mathrm{ab}$ & $90.5 \mathrm{a}$ & $92.8 \mathrm{ab}$ & $100.0 \mathrm{a}$ \\
\hline Fludioxonil & 300 & $3.4 \mathrm{c}$ & $28.6 \mathrm{~b}$ & $94.6 \mathrm{ab}$ & $6.7 \mathrm{c}$ & $66.7 \mathrm{ab}$ & $100.0 \mathrm{a}$ & $22.4 \mathrm{c}$ & $88.1 \mathrm{abc}$ & $100.0 \mathrm{a}$ \\
\hline
\end{tabular}

${ }^{\text {w }}$ Results are the mean of two experiments. For each column, values followed by different letters indicate significant differences according to general linear model and least significant difference mean separation procedures $(P \leq 0.05)$.

${ }^{\mathrm{x}}$ Fungicides were applied by a spray treatment using volumes that were approximately equivalent to 42 liters per $10,000 \mathrm{~kg}$ of fruit.

${ }^{y}$ Fruit were wound inoculated with each decay fungus (Monilinia fructicola, Botrytis cinerea, and Rhizopus stolonifer for brown rot, gray mold, and Rhizopus rot, respectively), incubated for 12 to $16 \mathrm{~h}$ at $20^{\circ} \mathrm{C}$, and then treated with fungicides.

${ }^{\mathrm{z}}$ Fruit were treated with fungicides, incubated for 5 to $12 \mathrm{~h}$ at $20^{\circ} \mathrm{C}$, and then wound inoculated with either decay fungus. 
using this inoculation-treatment schedule, iprodione was the most effective treatment, whereas fenhexamid, fludioxonil, and tebuconazole were very effective against gray mold on peach but not on nectarine. Fludioxonil and iprodione were the most effective treatments for Rhizopus rot control on peach, with decay incidences between 22.4 and $23.8 \%$, compared with $90 \%$ in the control. Treatment efficacy of these fungicides, however, was reduced on nectarine, with none providing excellent decay control. In addition, none of the fungicides provided excellent Rhizopus rot control on this stone fruit host. In contrast to these data on peach and nectarine, most pre-infection fungicide treatments had little or no effect on reducing decays of plum. The exception was tebuconazole, where brown rot was reduced to zero.

For fludioxonil, additional laboratory studies were conducted on nectarine and plum to determine the fungicide rate required to effectively reduce the development of decay caused by the three decay fungi evaluated. In linear regressions of the incidence of decay on fungicide concentration, $R^{2}$ values ranged from 0.73 to 0.99 , indicating a linear relationship between improved efficacy and increasing fungicide concentrations (Fig. 1). On nectarine, the 300-mg/liter rate resulted in no decay or in a very low incidence of the three decays (Fig. 1A). At rates of $200 \mathrm{mg} / \mathrm{liter}$, control of gray mold and Rhizopus rot also was excellent, whereas, for brown rot, decay compared with the control was reduced by $80 \%$. Rates of $100 \mathrm{mg} / \mathrm{liter}$ did not completely prevent the development of any of the three decays. On plum, the 300$\mathrm{mg} / \mathrm{liter}$ rate resulted in a brown rot incidence of $<10 \%$; whereas, for gray mold and Rhizopus rot, a rate of $600 \mathrm{mg} / \mathrm{liter}$ was required to obtain the same level of disease control (Fig. 1B).

Postharvest experimental packingline treatments for brown rot, gray mold, and Rhizopus rot control. The new fungicides that most consistently and effectively reduced the incidence of brown rot
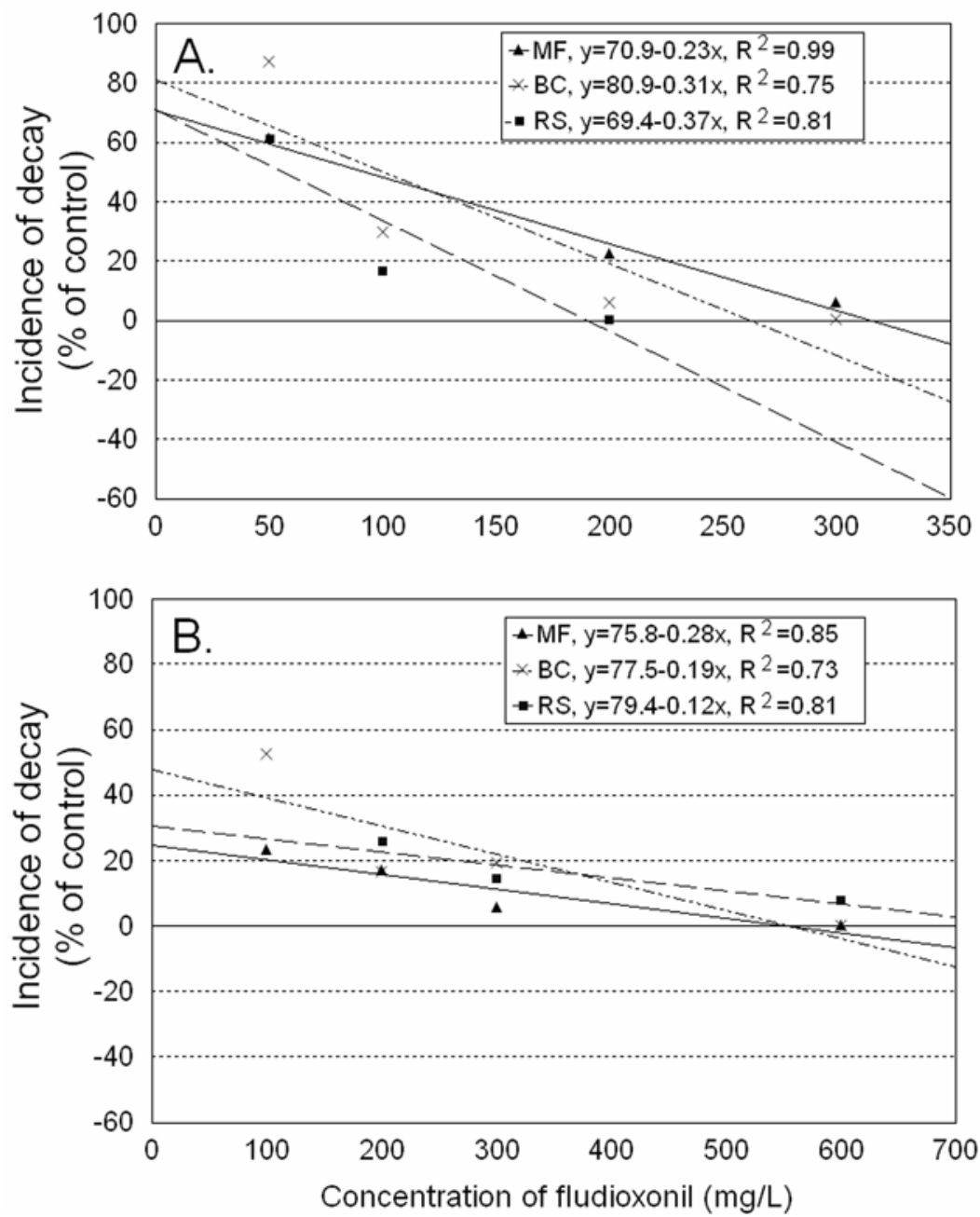

Fig. 1. Regressions of incidence of brown rot, gray mold, and Rhizopus rot on concentration of fludioxonil. Incidence of decay for $\mathbf{A}$, nectarine or $\mathbf{B}$, plum fruit was expressed as a percentage of the untreated control. Fruit were wound-inoculated with either Monilinia fructicola (Mf), Botrytis cinerea $(\mathrm{Bc})$, or Rhizopus stolonifer (Rs). Treatments with fludioxonil at selected concentrations were applied to fruit in the laboratory after $16 \mathrm{~h}$ for $\mathrm{Mf}$ and $\mathrm{Bc}$ and after 5 to $7 \mathrm{~h}$ for Rs. Fruit then were incubated for 4 to 6 days at $20^{\circ} \mathrm{C}$ and evaluated for incidence of decay. Symbols represent average values of three or four replications from each of two experiments. and gray mold in laboratory studies (i.e., fludioxonil, fenhexamid, and tebuconazole) also were evaluated in experimental packingline trials as low-volume spray applications over a brush bed. In studies on Elegant Lady peach and Red Diamond nectarine, treatment efficacies were compared with those of iprodione. The three general linear models used to evaluate fungicide treatments as affected by inoculation-treatment schedule, fruit crop (peach or nectarine), or decay pathogen all were highly significant $(P<0.0001)$. In addition, fungicide treatment, inoculationtreatment schedule, and their interaction, as well as fungicide treatment, decay pathogen, and their interaction were shown to be highly significant (Table 3 ). In the model to evaluate fungicide and fruit host, no significant difference was found between the two stone fruit hosts; however, a significant interaction (host-fungicide) indicated that the fungicides performed differently on the two hosts (Table 3). Thus, because significant interactions occurred between each of these three variables and the fungicide treatment, data in Table 4 are presented separately. Similar to the laboratory studies, excellent brown rot decay control was obtained after treatment with fludioxonil, fenhexamid, and tebuconazole when fruit were inoculated with the pathogens 12 to $16 \mathrm{~h}$ before treatment (Table 4). Incidence of decay using these fungicides was between 0 and $4.7 \%$ compared with 97.6 to $99.3 \%$ in the untreated control. Fludioxonil was the most effective new fungicide against gray mold on both stone fruit hosts, whereas fenhexamid was highly effective on nectarine but less effective on peach. Again, Rhizopus rot was reduced effectively by fludioxonil and tebuconazole (the latter fungicide was evaluated only on peach). Fenhexamid was not evaluated against Rhizopus rot because of lack of efficacy in the laboratory trials. Treatments of fruit before inoculation in most cases also significantly reduced decay of nectarine and peach, but efficacy generally was lower than when treatments were applied after wound inoculation (Table 4). For brown rot control, tebuconazole was the most effective treatment among the new fungicides, with $1 \%$ decay incidence on peach (tebuconazole was not included in the nectarine trials) compared with $96.9 \%$ incidence in the control. For fenhexamid and fludioxonil, the incidence of brown rot ranged from 11.5 to $19.6 \%$, compared with iprodione, where no decay developed on peach, and $24.4 \%$ incidence was found on the nectarine. For gray mold control, treatments were either not very effective (fludioxonil, 71.8 to $72.6 \%$ decay incidence) or intermediate in their efficacy (tebuconazole, only evaluated on peach with $45.8 \%$ decay incidence; fenhexamid, $41.5 \%$ incidence on peach and $21.4 \%$ incidence on nectarine). For Rhizopus rot control, efficacy was variable and decay 
incidence was reduced by only $<50 \%$ from the control by the best treatments (e.g., iprodione and tebuconazole on peach).

High- and low-volume application methods over a roller bed using fenhexamid and fludioxonil were compared on inoculated plum fruit. In the highvolume system, an aqueous in-line fungicide drench application was followed by a low-volume treatment with a carnaubabased fruit coating. In the low-volume spray system (6.7 liters per $10,000 \mathrm{~kg}$ of fruit), the fungicide was applied in a diluted fruit coating. General linear models were highly significant and the variables fungicide, application method, and their interaction were significant for both brown rot and gray mold (Table 5). Thus, data for fungicide and application method are presented separately for each decay fungus. nificantly improved decay control was and incidence using this latter application For both fenhexamid and fludioxonil, sigobtained using the high-volume system

method was $\leq 1.1 \%$ (Table 6 ). In comparison, for low-volume applications with fenhexamid, decay incidence was 40.4 and $24.3 \%$ and, with fludioxonil, 25.2 and $12 \%$ for brown rot and gray mold, respectively. Treatment efficacy against Rhizopus rot was evaluated only for fludioxonil. No decay developed after the in-line drench applications, whereas an incidence of $62.6 \%$ was observed after the low-volume spray treatment.

\section{DISCUSSION}

This is the first study comparing the efficacy of the fungicides fenhexamid, fludioxonil, and tebuconazole on different stone fruit crops and against the three major decays using application conditions that closely simulated fungicide treatments under commercial packingline conditions. Fenhexamid and fludioxonil were highly effective in managing postharvest brown rot and gray mold decays of stone fruit caused by $M$. fructicola and $B$. cinerea, respec-

Table 3. General linear model tables for disease incidence of fungicide-treated fruit using two postharvest inoculation procedures, two stone fruit crops (peach and nectarine), and three postharvest pathogens using data from two experimental packingline trials ${ }^{\mathrm{w}}$

\begin{tabular}{lcccc}
\hline Source & df & Mean square & $\boldsymbol{F}$ value & $\boldsymbol{P}>\boldsymbol{F}$ \\
\hline Inoculation schedule $^{\mathrm{x}}$ & 1 & $29,131.9$ & 93.84 & $<0.0001$ \\
Fungicide & 5 & $45,768.4$ & 147.43 & $<0.0001$ \\
Schedule-fungicide & 5 & $4,299.5$ & 13.85 & $<0.0001$ \\
Crop $^{y}$ & 1 & 14.3 & 0.03 & 0.86 \\
Fungicide & 5 & $43,128.5$ & 100.60 & $<0.0001$ \\
Crop-fungicide & 2 & $1,357.3$ & 2.96 & 0.053 \\
Pathogen $^{z}$ & 2 & $16,034.2$ & 44.58 & $<0.0001$ \\
Fungicide & 5 & $44,069.6$ & 122.53 & $<0.0001$ \\
Pathogen-fungicide & 9 & $1,554.2$ & 4.32 & $<0.0001$ \\
\hline
\end{tabular}

${ }^{\text {w}}$ Disease incidence was arcsine transformed and was based on the number of infected fruit per four replications of 12 to 24 fruit each. Variances among experiments were homogeneous according to Bartlett's test of homogeneity of variances. All general linear models were highly significant $(P<$ $0.0001)$.

${ }^{x}$ Inoculation-treatment schedule: fruit were treated either after $(12$ to $16 \mathrm{~h})$ or before inoculation.

${ }^{y}$ Peach and nectarine cultivars were Elegant Lady and Red Diamond, respectively.

${ }^{z}$ Pathogens used for inoculations were either Monilinia fructicola, Botrytis cinerea, or Rhizopus stolonifer. tively. Tebuconazole was more effective against brown rot than against gray mold. In addition, fludioxonil and tebuconazole also significantly reduced the incidence of Rhizopus rot caused by $R$. stolonifer. The QoI fungicide azoxystrobin that was evaluated in laboratory studies, however, was not as consistent in its activity. Thus, effective replacement treatments were identified for iprodione, a fungicide that was used successfully in postharvest applications by the California stone fruit industry until 1996. In the course of our studies, we first identified tebuconazole as a potential iprodione replacement; however, the development of this sterol-biosynthesis inhibiting fungicide was no longer supported by the EPA. In contrast, azoxystrobin, fenhexamid, and fludioxonil all are rated as "reduced-risk" materials (5).

Previously, fenhexamid, fludioxonil, and tebuconazole were evaluated as postharvest treatments of stone fruit $(1,10,13,15,16)$ and apple (9). For example, in studies on sweet cherry with tebuconazole (13) and on peach, nectarine, and plum with fludioxonil and fenhexamid $(1,2,10)$, we identified these fungicides as promising new postharvest treatments for control of brown rot, gray mold, and Rhizopus decays. A subsequent study by Northover and Zhou (16) confirmed that fludioxonil and tebuconazole effectively reduced the incidence of Rhizopus rot of peach. On plum, the incidence of brown rot developing from natural infections in the field was reduced significantly by postharvest 4-min soak treatments with tebuconazole and other sterol-biosynthesisinhibiting fungicides (15). Thus, our identification of fenhexamid and fludioxonil for postharvest use on different stone fruit crops against the three major decays and our comparative evaluations using application conditions that closely simulated commercial fungicide treatments have

Table 4. Evaluation of postharvest fungicide treatments for control of brown rot, gray mold, and Rhizopus rot of stone fruits in experimental packingline studies $^{\mathrm{w}}$

\begin{tabular}{|c|c|c|c|c|c|c|c|}
\hline \multirow[b]{2}{*}{ Treatment } & \multirow[b]{2}{*}{ Rates $(\mathrm{g} / \text { liter })^{\mathrm{x}}$} & \multicolumn{2}{|c|}{ Incidence of brown rot (\%) } & \multicolumn{2}{|c|}{ Incidence of gray mold (\%) } & \multicolumn{2}{|c|}{ Incidence of Rhizopus rot (\%) } \\
\hline & & Peach & Nectarine & Peach & Nectarine & Peach & Nectarine \\
\hline \multicolumn{8}{|c|}{ Inoculated, treated $\mathrm{y}$} \\
\hline Control & & $99.3 \mathrm{a}$ & $97.6 \mathrm{a}$ & $100.0 \mathrm{a}$ & $100.0 \mathrm{a}$ & $98.6 \mathrm{a}$ & $97.0 \mathrm{a}$ \\
\hline Iprodione & 7.2 & $0 \mathrm{c}$ & $0 \mathrm{~b}$ & $1.9 \mathrm{c}$ & $5.4 \mathrm{~b}$ & $63.9 \mathrm{~b}$ & $7.1 \mathrm{~b}$ \\
\hline Tebuconazole & 1.62 & $0 \mathrm{c}$ & ND & $26.0 \mathrm{~b}$ & ND & $17.7 \mathrm{c}$ & ND \\
\hline Fenhexamid & 5.4 & $4.7 \mathrm{~b}$ & $1.8 \mathrm{~b}$ & $20.1 \mathrm{~b}$ & $0.6 \mathrm{c}$ & ND & ND \\
\hline Fludioxonil & 1.8 & $1.0 \mathrm{bc}$ & $0 \mathrm{~b}$ & $9.1 \mathrm{c}$ & $0.6 \mathrm{c}$ & $13.5 \mathrm{c}$ & $3.0 \mathrm{~b}$ \\
\hline \multicolumn{8}{|c|}{ Treated, inoculated ${ }^{\mathrm{z}}$} \\
\hline Control & & $96.9 \mathrm{a}$ & $98.6 \mathrm{a}$ & $97.3 \mathrm{a}$ & $97.3 \mathrm{a}$ & $86.6 \mathrm{a}$ & 98.8 a \\
\hline Iprodione & 7.2 & $0 \mathrm{c}$ & $24.4 \mathrm{~b}$ & $17.9 \mathrm{~d}$ & $56.3 \mathrm{~b}$ & $48.1 \mathrm{~b}$ & $80.0 \mathrm{~b}$ \\
\hline Tebuconazole & 1.62 & $1.0 \mathrm{bc}$ & ND & $45.8 \mathrm{c}$ & ND & $52.1 \mathrm{~b}$ & ND \\
\hline Fenhexamid & 5.4 & $11.6 \mathrm{~b}$ & $11.5 \mathrm{~b}$ & $41.5 \mathrm{~cd}$ & $21.4 \mathrm{c}$ & ND & ND \\
\hline Fludioxonil & 1.8 & $12.0 \mathrm{bc}$ & $19.6 \mathrm{~b}$ & $71.8 \mathrm{~b}$ & $72.6 \mathrm{ab}$ & $70.8 \mathrm{ab}$ & $69.3 \mathrm{~b}$ \\
\hline
\end{tabular}

${ }^{\mathrm{w}}$ Results are the mean of two experiments. For each column, different letters after the numbers represent significant differences according to general linear model and least significant difference mean separation $(P \leq 0.05)$ procedures. $\mathrm{ND}=$ not done.

${ }^{\mathrm{x}}$ Fungicides were applied by a low-volume (6.7 liters per $10,000 \mathrm{~kg}$ of fruit) spray treatment.

${ }^{y}$ Fruit were wound inoculated with each decay fungus (Monilinia fructicola, Botrytis cinerea, and Rhizopus stolonifer for brown rot, gray mold, and Rhizopus rot, respectively), incubated for 12 to $16 \mathrm{~h}$ at $20^{\circ} \mathrm{C}$, and then treated with fungicides.

${ }^{\mathrm{z}}$ Fruit were treated with fungicides, incubated for 5 to $12 \mathrm{~h}$ at $20^{\circ} \mathrm{C}$, and then wound inoculated with either decay fungus. 
provided highly effective postharvest alternatives to the stone fruit industries.

Under current packinghouse practices in California, fruit typically are harvested in the morning and transported to the packinghouse, where they are stored at ambient conditions before postharvest treatments are applied on the same day. Because infections by the three major postharvest pathogens of stone fruit are initiated mainly from wounds that occur during or after harvest (1), fruit used in our studies or spores of the pathogens and then treated after an incubation period of up to $16 \mathrm{~h}$. To account for the control of decay that is initiated from infections during fruit handling after fungicide treatment such as additional sorting, packing, and shipping to market, we also evaluated the developtions that were done after fungicide applications. With several exceptions (e.g., tebuconazole against brown rot on all three stone fruit hosts, fludioxonil against brown rot and gray mold of peach, and fenwere wounded and inoculated with conidia ment of decay following wound inocula-

hexamid against gray mold of peach), applications that were done before wound inoculations were significantly less effective (Tables 1 to 4 ) and efficacy was less consistent than when fruit were treated after inoculation. In addition, treatments done before wound inoculation were more effective on peach fruit where, presumably, the trichomes can retain more fungicide compared with the smooth-skinned nectarine and plum fruit. On plum fruit with their waxy layer, none of the spray application treatments, except for tebuconazole against brown rot, resulted in satisfactory decay control. These results indicate that the fungicides are mainly wound-protection treatments that do not penetrate deeply enough into the fruit to prevent development of decay from wounds that extend below the epidermal layer, where fungicide concentrations are not sufficiently high.

Single rates were evaluated for azoxystrobin, fenhexamid, and tebuconazole in our studies because manufacturers supported these rates based on the preharvest registration of each product. In contrast,

Table 5. General linear model tables for disease incidence of fungicide-treated plum fruit using two postharvest application methods in experimental packingline trials ${ }^{\mathrm{y}}$

\begin{tabular}{lcccc}
\hline Pathogen, source $^{\mathbf{z}}$ & df & Mean square & $\boldsymbol{F}$ value & $\boldsymbol{P}>\boldsymbol{F}$ \\
\hline Monilinia fructicola & & & & \\
Fungicide & 2 & $16,709.7$ & 437.1 & $<0.0001$ \\
Application & 1 & $8,674.1$ & 226.9 & $<0.0001$ \\
Fungicide-application & 1 & 188.6 & 4.9 & 0.033 \\
Botrytis cinerea & & & & \\
Fungicide & 2 & $18,424.8$ & 588.0 & $<0.0001$ \\
Application & 1 & $4,152.7$ & 132.5 & $<0.0001$ \\
Fungicide-application & 1 & 66.2 & 2.1 & 0.015 \\
\hline
\end{tabular}

${ }^{y}$ Disease incidence was arcsine transformed and was based on the number of infected fruit per four replications of 40 fruit each. Variances among experiments were homogeneous according to Bartlett's test of homogeneity of variances. Both general linear models were highly significant $(P<$ $0.0001)$.

${ }^{\mathrm{z}}$ Plum fruit (cv. Casselman) were wound inoculated with either decay fungus, incubated for 14 to $16 \mathrm{~h}$ at $20^{\circ} \mathrm{C}$, and then treated with fungicides. Fungicides were applied by a low-volume (6.7 liters per $10,000 \mathrm{~kg}$ of fruit) spray treatment or by an in-line drench (approximately 42 liters per 10,000 kg of fruit).

Table 6. Evaluation of postharvest fungicide application methods for control of brown rot, gray mold, and Rhizopus rot of plum in experimental packingline studies

\begin{tabular}{|c|c|c|c|c|}
\hline \multirow[b]{2}{*}{ Treatment, rate ${ }^{y}$} & \multirow[b]{2}{*}{ Application method ${ }^{\mathrm{z}}$} & \multicolumn{3}{|c|}{ Incidence of decay $(\%)^{x}$} \\
\hline & & Brown rot & Gray mold & Rhizopus rot \\
\hline \multicolumn{5}{|l|}{ Fenhexamid } \\
\hline None & Control & $100.0 \mathrm{a}$ & $99.4 \mathrm{a}$ & ND \\
\hline $5.4 \mathrm{~g} / \mathrm{liter}$ & Low-volume spray & $40.4 \mathrm{~b}$ & $24.3 \mathrm{~b}$ & ND \\
\hline $900 \mathrm{mg} / \mathrm{liter}$ & In-line drench & $0.5 \mathrm{c}$ & $1.1 \mathrm{c}$ & ND \\
\hline \multicolumn{5}{|l|}{ Fludioxonil } \\
\hline None & Control & $100.0 \mathrm{a}$ & $99.4 \mathrm{a}$ & $68.5 \mathrm{a}$ \\
\hline $1.8 \mathrm{~g} /$ liter & Low-volume spray & $25.2 \mathrm{~b}$ & $12.0 \mathrm{~b}$ & $62.6 \mathrm{a}$ \\
\hline $300 \mathrm{mg} / \mathrm{liter}$ & In-line drench & $0.5 \mathrm{c}$ & $0 \mathrm{c}$ & $0 \mathrm{~b}$ \\
\hline
\end{tabular}

${ }^{\mathrm{x}}$ Results are the mean of two experiments. For each fungicide-decay pathogen combination, values followed by different letters represent significant differences between application methods according to general linear model and least significant difference mean separation procedures $(P>0.05)$. ND $=$ not done.

${ }^{y}$ Fruit were wound inoculated with each decay fungus (Monilinia fructicola, Botrytis cinerea, and Rhizopus stolonifer for brown rot, gray mold, and Rhizopus rot, respectively), incubated for 14 to 16 $\mathrm{h}$ at $20^{\circ} \mathrm{C}$, and then treated with fungicides. At the rates indicated, similar theoretical amounts of fungicide were applied to the fruit using the two application methods.

${ }^{\mathrm{z}}$ Fungicides were applied by a low-volume (6.7 liters per $10,000 \mathrm{~kg}$ of fruit) spray treatment or by an in-line drench (approximately 42 liters per $10,000 \mathrm{~kg}$ of fruit). for fludioxonil, several rates were evaluated in laboratory experiments. Our regression analyses of fludioxonil concentrations indicated that a rate equivalent to 300 $\mathrm{mg} /$ liter, based on a treatment volume of 41 liters per $10,000 \mathrm{~kg}$ of fruit, will result in satisfactory decay control. Based on these data, a minimum rate of $12.5 \mathrm{~g}$ per $10,000 \mathrm{~kg}$ was recommended for the label of this fungicide for a range of application methods.

Currently, postharvest fungicide treatments of stone fruit crops in California are most commonly applied as in-line, lowvolume sprays. Therefore, most of our fungicide evaluations were done using spray treatments either in the laboratory or on an experimental packingline. Commercial sprays are done to wet, washed fruit mostly at low volumes ( 0.42 to 10.4 liters per $10,000 \mathrm{~kg}$ of fruit) to minimize fungicide run-off that may contaminate wastewater. These treatments can be highly effective on peach and nectarine. However, as demonstrated in our studies on plum, these applications may have limitations when applied over a roller bed. Here, in contrast to brush bed applications, the treatment solution may not be as uniformly distributed over the fruit surface and may not be deposited as well into wound depressions, although the total amount of fungicide on the fruit may be similar for both methods. In packinghouses, roller bed applications often are done on plum because fruit retain most of their natural waxy bloom, which is preferred in some markets. In our comparative studies using spray or in-line, high-volume drench applications over a roller bed to treat inoculated plum fruit, we demonstrated that the drench applications were significantly more effective in reducing postharvest decays (Tables 5 and 6). Very low decay levels occurred using either fenhexamid or fludioxonil $(\leq 1.1 \%)$, whereas decay incidence was between 25.2 and $40.4 \%$ for brown rot, between 12.0 and $24.3 \%$ for gray mold, or $62.6 \%$ for Rhizopus rot (fludioxonil only) after the low-volume spray application. Previously, postharvest bin-drench treatments of fruit that are a common practice in other stone fruitgrowing areas (16) have been criticized based on the discharge of excess fungicide in the wastewater and potential build-up of microbial populations in the fungicide solution. Because the fungicide solution can be recirculated easily for in-line drench applications, fungicide run-off is minimized. In addition, by treating only fruit that are washed and sanitized, contamination of the fungicide solutions with pathogen propagules is kept to a minimum. Furthermore, fludioxonil is especially suited for recirculating drench applications because it is very stable in solutions containing sodium hypochlorite at concentrations of $100 \mathrm{mg} / \mathrm{liter}$ (J. E. Adaskaveg, unpublished) and, thus, sodium hypochlo- 
rite can be added as a sanitizer to the fungicide solution. This type of application with fludioxonil currently is being done successfully on pomegranate in California (22) and could be adapted easily to treat other commodities as well.

In vitro fungicide sensitivities were determined for $M$. fructicola and B. cinerea using fenhexamid and fludioxonil. The spiral gradient dilution method that was developed previously in our laboratory (11) was used in these studies with a slight modification of the procedure. To determine fungicide $\mathrm{EC}_{50}$ values for mycelial growth, instead of mycelium-covered cellophane strips, conidial suspensions were plated along the radial fungicide concentration gradient on the agar plates. This further simplified this high-throughput method and it could be done because fenhexamid and fludioxonil are not as effective against conidial germination compared with mycelial growth of the two fungi evaluated (11). Although only 14 isolates of $B$. cinerea from stone fruit crops were included in this study, a similar range of sensitivity against fenhexamid and fludioxonil was obtained using a large collection of isolates of this pathogen from decayed pear fruit in California (J. E. Adaskaveg and H. Förster, unpublished). The low $\mathrm{EC}_{50}$ values obtained indicate that both decay fungi are very sensitive to both fungicides, supporting the high efficacy in our fruit inoculation studies. Isolates of $B$. cinerea resistant to fenhexamid, however, were identified by others using discriminatory fungicide concentrations in in vitro sensitivity assays $(7,14)$. Although sensitivities of the majority of the 234 isolates that were collected from a variety of non-stone fruit crops in California were similar to the ones in our study, $\mathrm{EC}_{50}$ values for four isolates were greater than 2.8 $\mathrm{mg} /$ liter (14). Fenhexamid-resistant isolates of $B$. cinerea, as identified by growth at a discriminatory concentration of $0.1 \mathrm{mg} / \mathrm{liter}$, also were found in field collections from grape in Switzerland after several years of applications with this fungicide (7). In contrast, no isolates resistant to fludioxonil were found in this latter study. These observations may be an indication of different resistance potentials between the two fungicides. In addition, they emphasize the importance of establishing baseline sensitivities that can be used in fungicide resistance monitoring programs.

Through this research, new postharvest fungicides are becoming available to the stone fruit industries of California and other production areas in the United States. The efficacy of the broad-spectrum phenylpyr- role fludioxonil (12) equals or even exceeds that of iprodione. The hydroxyanilide fenhexamid, with a more narrow-spectrum activity (20), is an excellent gray mold and brown rot management tool. In 2003, fludioxonil was federally registered for postharvest use in the United States and also received its state registration in California. Fenhexamid received its federal and California registrations in 2005 . With their reduced-risk classification, these fungicides impose a minimal risk to human health and the environment. They will be essential in the long-distance shipment of fruit and will be critical in securing the future of the California stone fruit industry. We continue to evaluate new materials as potential new postharvest fungicides. No resistance against fenhexamid or fludioxonil has been detected to date in the stone fruit pathogen populations. Still, effective fungicide resistance management programs have to be developed and implemented that include the use of several active compounds. Effective strategies in pre- and postharvest disease management will depend on mixtures and rotations of fungicides with different modes of action. In addition, proper postharvest application procedures that result in adequate fungicide residues on the fruit as well as the appropriate disposal of fungicide runoff and of fungicide-treated culls are fundamental for the stewardship of these compounds with a single-site mode of action.

\section{ACKNOWLEDGMENTS}

We thank the California Tree Fruit Agreement for financial support of this research.

\section{LITERATURE CITED}

1. Adaskaveg, J. E., Förster, H., Gubler, W. D., Teviotdale, B. L., and Thompson, D. F. 2005. Reduced-risk fungicides help manage brown rot and other fungal disease of stone fruit. Calif. Agric. 59:109-114.

2. Adaskaveg, J. E., Förster, H., and Sommer, N. F. 2002. Principles of postharvest pathology and management of decays of edible horticultural crops. Pages 163-195 in: Postharvest Technology of Horticultural Crops, 4th ed.. A. Kader, ed. University of California DANR Publ. 3311, Oakland, CA.

3. Adaskaveg, J. E., Förster, H., and Thompson, D. F. 2000. Identification and etiology of visible quiescent infections of Monilinia fructicola and Botrytis cinerea in sweet cherry fruit. Plant Dis. 84:328-333.

4. Adaskaveg, J. E., and Ogawa, J. M. 1994. Penetration of iprodione into mesocarp fruit tissue and suppression of gray mold and brown rot of sweet cherries. Plant Dis. 78:293-296.

5. Anonymous. 2003. Reducing pesticide risk. United States Environmental Protection Agency. Published online.

6. Atlas, R. M. 1993. Handbook of Microbiological Media. L. C. Parks, ed. CRC Press, Boca Raton, FL.

7. Baroffio, C. A., Siegfried, W., and Hilber, U.
W. 2003. Long-term monitoring for resistance of Botryotinia fuckeliana to anilinopyrimidine phenylpyrrole, and hydroxyanilide fungicides in Switzerland. Plant Dis. 87:662-666.

8. Emery, K. M., Michailides, T. J., and Scherm, H. 2000. Incidence of latent infections of immature peach fruit by Monilinia fructicola and relationship to brown rot in Georgia. Plant Dis. 84:853-857.

9. Errampalli, D. 2004. Effect of fludioxonil on germination and growth of Penicillium expansum and decay in apple cvs. Empire and Gala. Crop Prot. 23:811-817.

10. Förster, H., and Adaskaveg, J. E. 1999. Fludioxonil, a new reduced risk postharvest fungicide for management of fungal decays of stone fruit. (Abstr.) Phytopathology 89:S26.

11. Förster, H., Kanetis, L., and Adaskaveg, J. E. 2004. Spiral gradient dilution, a rapid method for determining growth responses and 50\% effective concentration values in fungusfungicide interactions. Phytopathology 94:163170.

12. Gehmann, K., Nyfeler, R., Leadbeater, A. J., Nevill, D., and Sozzi, D. 1990. CGA 173506 A new fungicide for broad-spectrum disease control. Pages 399-406 in Proc. Brighton Crop Prot. Conf. Pests Dis. BCPC, Farnham, Surrey, UK.

13. Kim, D. H., Hartin, R. J., and Adaskaveg, J. E. 1997. Evaluation of new, potential postharvest fungicides efficacy for management of brown rot, gray mold, and Rhizopus rot decay of sweet cherry. (Abstr.) Phytopathology 87:S51.

14. Ma, Z. H., and Michailides, T. J. 2005. Genetic structure of Botrytis cinerea populations from different host plants in California. Plant Dis. 89:1083-1089.

15. Northover, J., and Cerkauskas, R. F. 1998. Fungicidal suppression of symptomless latent infections of Monilinia fructicola in European plums. Can. J. Plant Pathol. 20:234-242.

16. Northover, J., and Zhou, T. 2002. Control of Rhizopus rot of peaches with postharvest treatments of tebuconazole, fludioxonil, and Pseudomonas syringae. Can. J. Plant Pathol. 24:144-153.

17. Ogawa, J. M., Adaskaveg, J. E., and Conn, K. E. 1992. Efficacy of iprodione-wax/oil mixtures for control of post-harvest decay of fruit caused by Rhizopus and Alternaria spp. (Abstr.) Phytopathology 82:1064.

18. Ogawa, J. M., and English, H. 1991. Disease of temperate zone tree fruit and nut crops. Univ. Calif. Div. Agric. Nat. Res. Oakland, CA. Public. No. 3345.

19. Ribeiro, O. K. 1978. A Source Book of the Genus Phytophthora. J. Cramer, Vaduz, Liechtenstein.

20. Rosslenbroich, H. J., Brandes, W., Krueger, B. W., Kuck, K. H., Pontzen, R., Stenzel, K., and Suty, A. 1998. Fenhexamid (KBR 2738)-a novel fungicide for control of Botrytis cinerea and related pathogens. Pages 327-334 in Proc. Brighton Crop Prot. Conf. Pests Dis. BCPC, Farnham, Surrey, UK.

21. Snowdon, A. L. 1990. A Colour Atlas of PostHarvest Diseases and Disorders of Fruits and Vegetables. Wolfe Scientific, Barcelona, Spain.

22. Tedford, E. C., Adaskaveg, J. E., and Ott, A. J. 2005. Impact of Scholar (a new post-harvest fungicide) on the California pomegranate industry. Online. Plant Health Progress doi:10.1094/PHP-2005-0216-01-PS 